\title{
ARTICLE
}

Received 9 Nov 2012 | Accepted 28 Feb 2013 | Published 3 Apr $2013 \quad$ DOl: 10.1038/ncomms2662

\section{Mass spectrometric analysis of mono- and multi-phosphopeptides by selective binding with $\mathrm{NiZnFe}_{2} \mathrm{O}_{4}$ magnetic nanoparticles}

Hongying Zhong ${ }^{1}, X_{i a o}$ Xiao $^{1, \star}$, Shi Zheng ${ }^{1, \star}$, Wenyang Zhang ${ }^{1}$, Mengjie Ding $^{1}$, Haiying Jiang ${ }^{1}$, Lulu Huang ${ }^{1}$ \& Jie Kang ${ }^{1}$

Selective isolation of mono- and multi-phosphorylated peptides is important for understanding how a graded protein kinase or phosphatase signal can precisely modulate the on and off states of signal transduction pathways. Here we report that metal ions at exposed octahedral sites of nano-ferrites, including $\mathrm{Fe}_{3} \mathrm{O}_{4}, \mathrm{NiFe}_{2} \mathrm{O}_{4}, \mathrm{ZnFe}_{2} \mathrm{O}_{4}$ and $\mathrm{NiZnFe}_{2} \mathrm{O}_{4}$, have distinctly selective coordination abilities with mono- and multi- phosphopeptides. Due to their intrinsic magnetic properties and high surface area to volume ratios, these nanoparticles enable the rapid isolation of mono- and multi-phosphopeptides by an external magnetic field. Model phosphoprotein $\alpha$-casein and two synthesized mono- and di-phosphopeptides have been chosen for proof-of-principle demonstrations, and these nanoparticles have also been applied to phosphoproteome profiling of zebrafish eggs. It is shown that $\mathrm{NiZnFe}_{2} \mathrm{O}_{4}$ is highly selective for multi-phosphopeptides. In contrast, $\mathrm{Fe}_{3} \mathrm{O}_{4}, \mathrm{NiFe}_{2} \mathrm{O}_{4}$ and $\mathrm{ZnFe}_{2} \mathrm{O}_{4}$ can bind with both mono- and multi-phosphopeptides with relatively stronger affinity towards monophosphopeptides.

\footnotetext{
${ }^{1}$ Key Laboratory of Pesticides and Chemical Biology, Ministry of Education, College of Chemistry, Central China Normal University, Wuhan 430079, China.

* These authors contributed equally to this work. Correspondence and requests for materials should be addressed to H.Z. (email: hyzhong@mail.ccnu.edu.cn).
} 
R eversible protein phosphorylation is an important regulatory mechanism for prokaryotic and eukaryotic cells ${ }^{1,2}$. Cycles of phosphorylation and dephosphorylation cause conformational changes in structures of many enzymes and receptors and also function as electrostatic switches to modulate the on and off states of many signalling pathways ${ }^{3-5}$.

Processive multisite phosphorylation cascades have been implicated in the regulation of many cell behaviours such as graded activity-dependent regulation of ion channel gating ${ }^{6}$, proper tuning of cell cycles ${ }^{7}$ and graded enhancement of protein interactions $s^{8,9}$. Differentiation of mono- and multi-phosphopeptides offers compelling biological insights into their distinct functions. For example, mono- and di-phosphorylation of myosin light chain differentially regulate adhesion and polarity in migrating cells ${ }^{10}$; but mono- and multisite phosphorylation of $\mathrm{Bcl} 2$ either enhances its antiapoptotic function or inactivates $\mathrm{Bcl} 2^{11}$. These experimental results suggest the functional and regulatory advantages of different levels of phosphorylation in the processing of complex cellular information. The regulated sequential or simultaneous binding of phosphate groups in multisites or just a single site with proteins may function as dynamic structural 'codes' in response to different physiological status or environmental stresses ${ }^{12}$. However, the distributions of these phospho-isoforms and the mechanisms how the dynamic structural 'codes' are regulated remain largely unknown. It is urgently necessary to explore new avenues that can not only isolate phosphorylated peptides from nonphosphorylated peptides, but also can further dissect the levels of phosphorylation with high resolution ${ }^{13,14}$.

Magnetic nanoparticles of ferrites (mNOF) and transition metal ion doped ferrites (for example, $\mathrm{Ni}^{2+}$ and $\mathrm{Zn}^{2+}$ ) ${ }^{15-17}$ have been studied because of their distinct magnetic and electrical properties $^{18-20}$, chemical and thermal stabilities ${ }^{21,22}$, coordination abilities of exposed octahedral metal ions ${ }^{22}$ as well as high ratios of surface area to volume. We demonstrate here that different metal ions at the surface octahedral sites of $\mathrm{NiZnFe}_{2} \mathrm{O}_{4}, \mathrm{Fe}_{3} \mathrm{O}_{4}, \mathrm{NiFe}_{2} \mathrm{O}_{4}$ and $\mathrm{ZnFe}_{2} \mathrm{O}_{4}$ nanoparticles have distinctly different binding affinities towards multi- and monophosphopeptides. All these features makes mNOF an ideal new tool for in-depth studies of phosphoproteomes.

\section{Results}

Selective binding of ferrites with phosphopeptides. Binding of $\mathrm{Fe}^{3+}$ or other transition metal ions with negatively charged phosphate groups has been demonstrated in IMAC (immobilized metal ion affinity chromatography) experiments ${ }^{23-25}$ in which metal ions are chelated to a resin. Essentially, these metal ions can bind with both mono- and multi-phosphorylated peptides, while multi-phosphorylated peptides appear to have stronger binding affinities because of stronger electrostatic interactions.

Binding affinities of metal ions present in $\mathrm{Fe}_{3} \mathrm{O}_{4}, \mathrm{NiFe}_{2} \mathrm{O}_{4}$, $\mathrm{ZnFe}_{2} \mathrm{O}_{4}$ and $\mathrm{NiZnFe}_{2} \mathrm{O}_{4}$ nanoparticles have been investigated in this work. MALDI-MS (matrix assisted laser desorption ionization-mass spectrometry) was used for methodology demonstration because it minimizes losses of multi-phosphorylated peptides that are often confronted with liquid chromatography-mass spectrometry approaches ${ }^{26}$. Tryptic peptides of $\alpha$-casein were loaded in $50 \%$ ACN (acetonitrile) containing $0.1 \%$ TFA (trifluoroacetic acid) and eluted with $1 \mathrm{M}$ ammonium phosphate as described in Methods. In contrast with IMAC, dominant peptides eluted from $\mathrm{Fe}_{3} \mathrm{O}_{4}$ are monophosphopeptides (Fig. 1a), while weak peaks at $m / z=2,720$ and $m / z=1,927$ that are identified as multiphosphopeptides with either 5 or 2 phosphate groups are also detected. Similar results were observed for $\mathrm{NiFe}_{2} \mathrm{O}_{4}$ (Supplementary Fig. S1a) and $\mathrm{ZnFe}_{2} \mathrm{O}_{4}$ nanoparticles (Supplementary Fig. S1b). However, completely different multiphosphopeptides were found to elute from $\mathrm{NiZnFe}_{2} \mathrm{O}_{4}$ nanoparticles (Fig. 1b), indicating that $\mathrm{NiZnFe}_{2} \mathrm{O}_{4}$ has highly selective binding affinity towards multiphosphorylated peptides. Figure $1 \mathrm{c}, \mathrm{d}$ shows the binding schemes for $\mathrm{Fe}_{3} \mathrm{O}_{4}$ and $\mathrm{NiZnFe}_{2} \mathrm{O}_{4}$ nanoparticles, respectively.

In order to further confirm binding selectivities of different ferrites, flowthrough fractions of different ferrites have been inversely enriched by each other. As expected, monophosphorylated peptides were detected in the flowthrough fraction of $\mathrm{NiZnFe}_{2} \mathrm{O}_{4}$ (Fig. 1e) and multi-phosphorylated peptides were detected in the flowthrough fraction of $\mathrm{Fe}_{3} \mathrm{O}_{4}$ (Fig. 1f). Multi-phosphorylated peptides present in Fig. 1a (peaks at $m / z=2,720$ and $m / z=1,927$ ) were not observed in the flowthrough fraction of $\mathrm{NiZnFe}_{2} \mathrm{O}_{4}$ (Fig. 1e). These experimental results demonstrate that $\mathrm{NiZnFe}_{2} \mathrm{O}_{4}$ can selectively capture multiphosphorylated peptides but $\mathrm{Fe}_{3} \mathrm{O}_{4}$ can bind with both monoand multi- phosphopeptides with relatively stronger affinities towards monophosphopeptide. Therefore, a sequential loading of samples with $\mathrm{NiZnFe}_{2} \mathrm{O}_{4}$ followed by $\mathrm{Fe}_{3} \mathrm{O}_{4}$ was performed in order to differentiate multi- and mono- phosphorylated peptides. By using this approach, all phosphorylation sites of $\alpha$-casein was recovered (Supplementary Table S1). Further separation of multi-phosphopeptides bound with $\mathrm{NiZnFe}_{2} \mathrm{O}_{4}$ can not be achieved through gradient elution by using $20 \mathrm{mM}, 50 \mathrm{mM}$, $100 \mathrm{mM}$ and $1 \mathrm{M}\left(\mathrm{NH}_{4}\right)_{3} \mathrm{PO}_{4}$ (Fig. $2 \mathrm{a}-\mathrm{d}$ ). The strong tolerance of $\mathrm{NiZnFe}_{2} \mathrm{O}_{4}$ and $\mathrm{Fe}_{3} \mathrm{O}_{4}$ to co-existed chemical reagents and other non-phosphorylated peptides in samples was shown in Supplementary Note 1 and Supplementary Fig. S2.

Effects of experimental conditions. The experimentally optimized loading condition for $\mathrm{Fe}_{3} \mathrm{O}_{4}$ and $\mathrm{NiZnFe}_{2} \mathrm{O}_{4}$ is a solution containing $50 \%$ ACN and $0.1 \%$ TFA (Fig. 1). Both $\mathrm{pH}$ value and the organic solvent have critical roles in the binding specificities. As for $\mathrm{Fe}_{3} \mathrm{O}_{4}$, three non-phosphopeptides including HIQKEDVPSER (1,337 Da), HQGLPQEVLNENLLR (1,759 Da) and EPMIGVNQELAYFY$\operatorname{PELFR}(2,316 \mathrm{Da})$ as well as an impurity peak at $m / z=1,116 \mathrm{Da}$ were observed under a weaker acidic condition of $0.01 \%$ TFA (Supplementary Fig. S3a). All three peptides has at least two glutamic acid residues that can provide carboxyl groups to interact with metal ions. Loading of samples in solutions without acetonitrile also causes non-specific binding (Supplementary Fig. S3b). Delightedly, $\mathrm{Fe}_{3} \mathrm{O}_{4}$ has strong tolerance to $0.01 \%$ SDS (Supplementary Fig. S3c) or even $0.1 \%$ SDS (Supplementary Fig. S3d) that is commonly used for biological sample preparations. The same sample loading conditions have been evaluated for $\mathrm{NiZnFe}_{2} \mathrm{O}_{4}$. It was shown that $\mathrm{pH}$ value (Supplementary Fig. S3e), organic solvent composition (Supplementary Fig. S3f) and SDS concentration (Supplementary Fig. S3g,h) do not significantly affect the binding selectivity of $\mathrm{NiZnFe}_{2} \mathrm{O}_{4}$ towards multi-phosphopeptides. However, signal-tonoise ratios in Supplementary Fig. S3e-h are significantly lower than that in optimized condition (Fig. 1). It means that experimental conditions do exert effects on recoveries of multi-phosphopeptides. Similar results were observed for $\mathrm{NiFe}_{2} \mathrm{O}_{4}$ (Supplementary Fig. S4) and $\mathrm{ZnFe}_{2} \mathrm{O}_{4}$ (Supplementary Fig. S5). But $\mathrm{Fe}_{3} \mathrm{O}_{4}$ and $\mathrm{NiZnFe}_{2} \mathrm{O}_{4}$ were chosen for downstream sample analysis because they have better magnetic properties than $\mathrm{NiFe}_{2} \mathrm{O}_{4}$ and $\mathrm{ZnFe}_{2} \mathrm{O}_{4}$.

Assessment of the binding performance of $\mathrm{NiZnFe}_{2} \mathrm{O}_{4}$. The intrinsic difficulties of MALDI mass spectrometer in ion suppression, ionization and especially heterogeneous crystallization of DHB matrix (2, 5-dihydroxybenzoic acid) limit its application to quantitative analysis by using absolute intensities. In order to quantitatively assess the detection limit, two synthesized peptides $\mathrm{P} 1$ and P2 (in 1:1 molar ratio) with 1 or 2 phosphate groups were loaded with $\mathrm{NiZnFe}_{2} \mathrm{O}_{4}$ nanoparticles and 
a

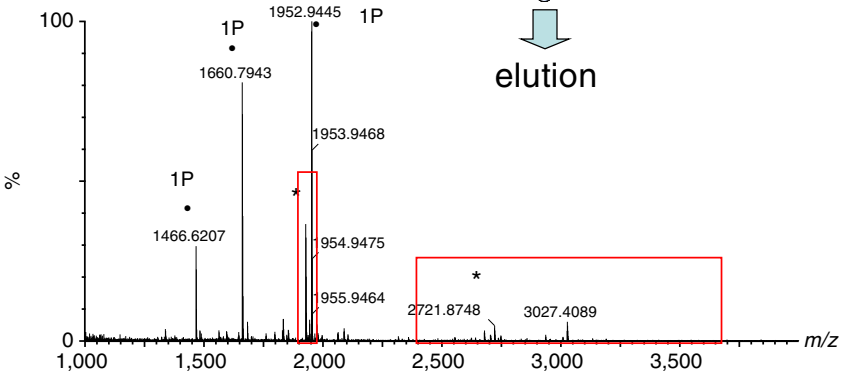

b

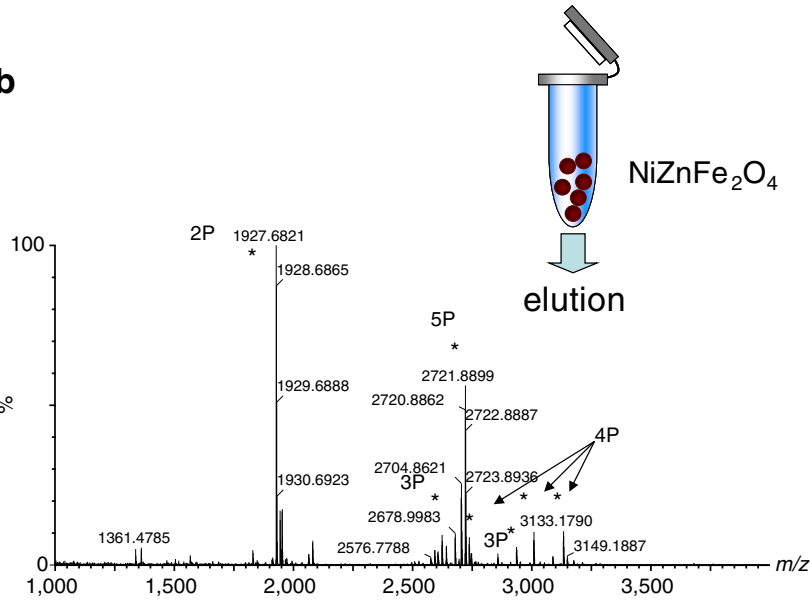

c

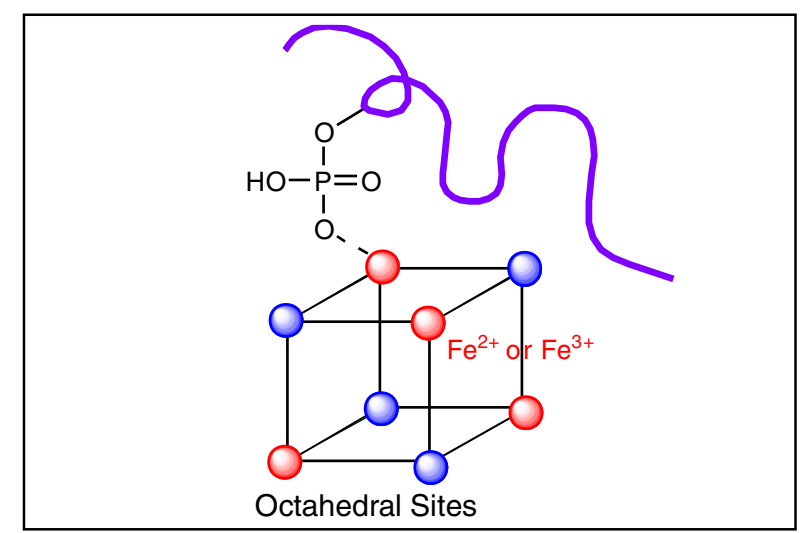

d

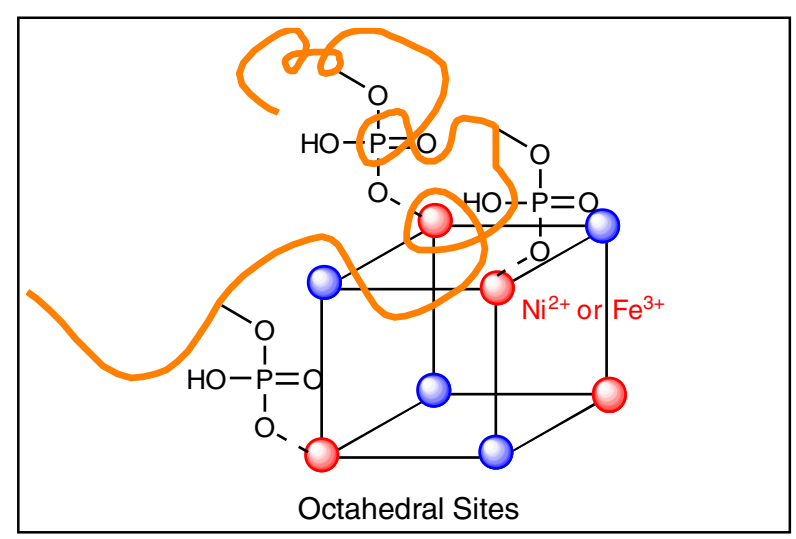

e

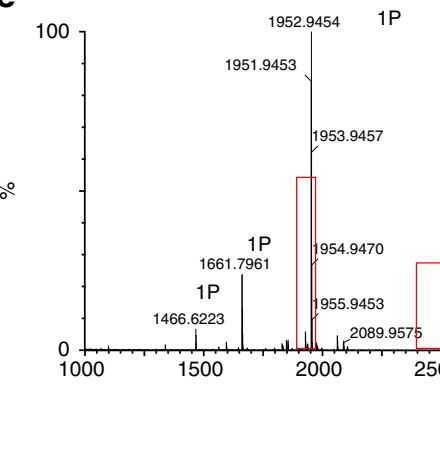

Flowthrough

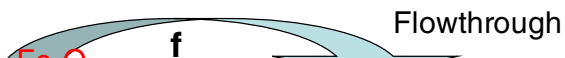

Flowthrough

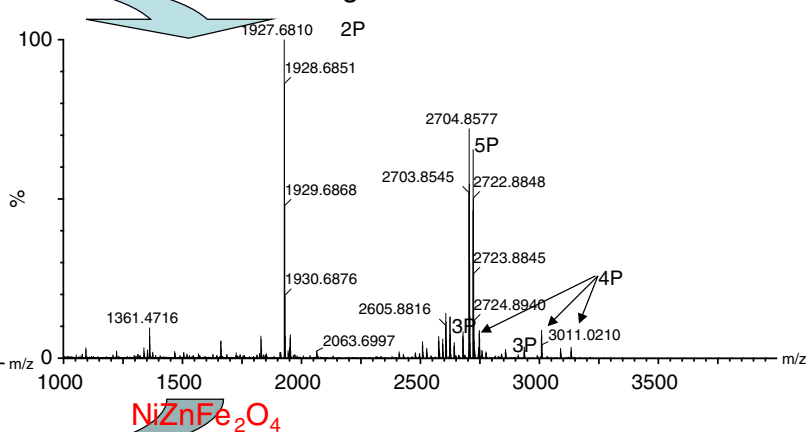

Figure 1 | Selective binding of $\mathrm{Fe}_{3} \mathrm{O}_{\mathbf{4}}$ and $\mathrm{NiZnFe}_{\mathbf{2}} \mathrm{O}_{\mathbf{4}}$ nanoparticles towards mono- and multi- phosphorylated peptides. (a,b) Mass spectra of peptides directly enriched from tryptic digests of $\alpha$-casein with $\mathrm{Fe}_{3} \mathrm{O}_{4}$ and $\mathrm{NiZnFe}_{2} \mathrm{O}_{4}$ nanoparticles. Monophosphopeptides and multi-phosphopeptides are shown as black balls and stars, respectively. Phosphorylations were labelled as P. Red squares indicate that multi-phosphorylated peptides can also be detected in the elutant from $\mathrm{Fe}_{3} \mathrm{O}_{4}$ nanoparticles. (c,d) Binding schematic for $\mathrm{Fe}_{3} \mathrm{O}_{4}$ and $\mathrm{NiZnFe}_{2} \mathrm{O}_{4}$ nanoparticles. Blue balls represent oxygen atoms at cubic lattices. Metal ions at surface octahedral sites are shown as red balls. Exposed surface octahedral metal ions can provide free coordination sites to accept electron pairs donated by negatively charged phosphate groups. (e) Mass spectrum of peptides inversely enriched with $\mathrm{Fe}_{3} \mathrm{O}_{4}$ from the flowthrough fraction of $\mathrm{NiZnFe}_{2} \mathrm{O}_{4}$. Red squares indicate that multi-phosphorylated peptides can not be detected after efficient $\mathrm{NiZnFe}_{2} \mathrm{O}_{4}$ capture. (f) Mass spectrum of peptides inversely enriched with $\mathrm{NiZnFe}_{2} \mathrm{O}_{4}$ from the flowthrough fraction of $\mathrm{Fe}_{3} \mathrm{O}_{4}$. Mono- phosphorylated peptides were not detected. Some unlabelled peaks with low intensities may result from in source fragmentation, formation of adducts, non-specific interactions, unknown impurities as well as interferences of peptides with carboxyl groups. False identification can be avoided by further MS/MS experiments and MASCOT database searching. In all these experiments, tryptic peptides of $\alpha$-casein were loaded with nanoparticles in optimized solutions containing $50 \%$ ACN and $0.1 \%$ TFA.

eluted with $1 \mathrm{M}\left(\mathrm{NH}_{4}\right)_{3} \mathrm{PO}_{4}$. After ZipTip desalting, the final elutant was mixed with CHCA ( $\alpha$-cyano-4-hydroxycinnamic acid) instead of DHB for MALDI analysis here. The detection limit of $\mathrm{NiZnFe}_{2} \mathrm{O}_{4}$ can be down to $0.3 \mathrm{pmol}$ with a reasonable $\mathrm{S} / \mathrm{N}$ ratio, while the high selectivity towards multi-phosphopeptides is still remained (Supplementary Fig. S6). It should be indicated that the detection limit is not only associated with enrichment methods but also highly related with sample preparation methods and instruments. In addition, although DHB undergoes heterogeneous crystallization, it is better than CHCA for ionization of 
a
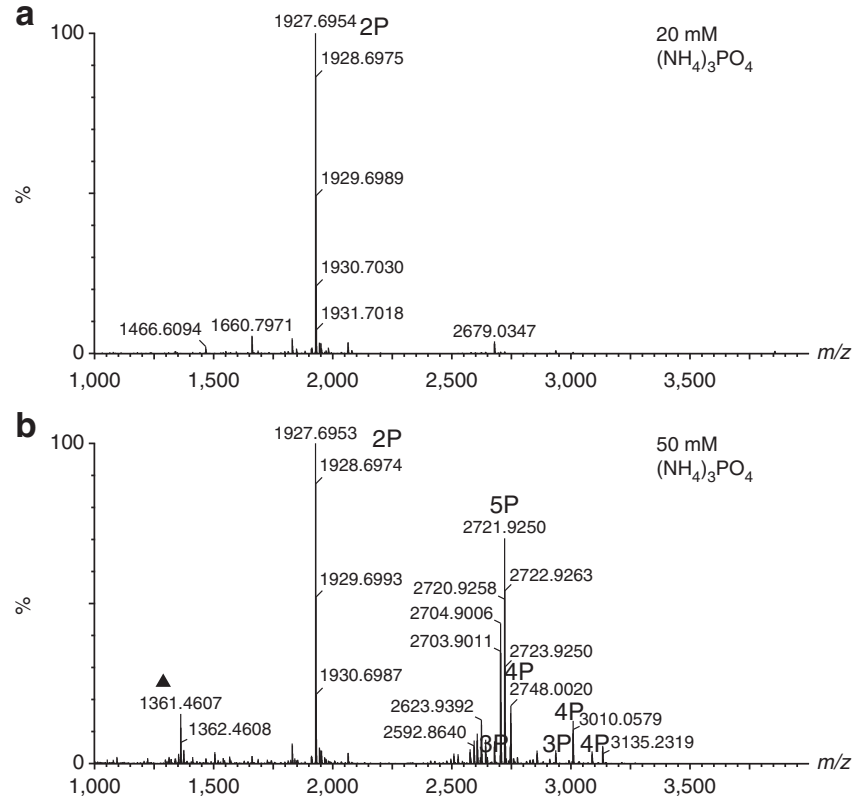

c
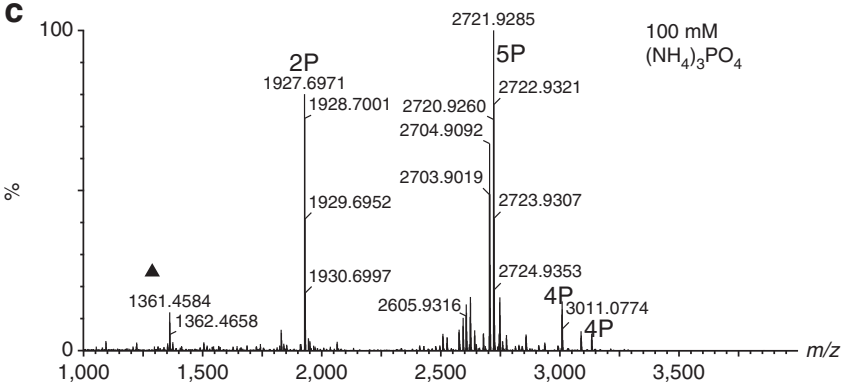

d

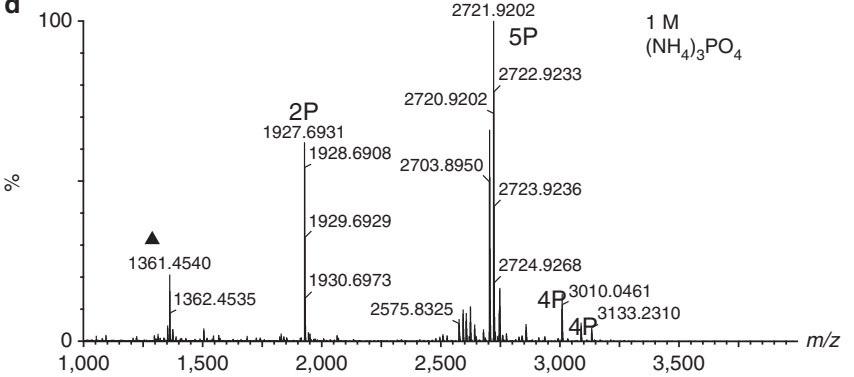

Figure 2 | Differences in binding affinities of $\mathrm{NiZnFe}_{2} \mathrm{O}_{4}$ nanoparticles towards peptides with different levels of phosphorylation. (a-d) Mass spectra of multi-phosphopeptides of $\alpha$-casein sequentially eluted from $\mathrm{NiZnFe}_{2} \mathrm{O}_{4}$ nanoparticles by using gradient $20 \mathrm{mM}$ (a), $50 \mathrm{mM}$ (b), $100 \mathrm{mM}(\mathbf{c})$ and $1 \mathrm{M}(\mathbf{d})\left(\mathrm{NH}_{4}\right)_{3} \mathrm{PO}_{4}$, respectively. Only di-phosphopeptides at $m / z=1927$ is partially separated from other multi-phosphopeptides (a). Phosphopeptides with more than two phosphate groups can not be differentiated with $\mathrm{NiZnFe}_{2} \mathrm{O}_{4}$ nanoparticles. Black triangles represent interferences of unknown peaks.

phosphopeptides. On the basis of these considerations, higher amounts of samples and DHB are recommended for sample analysis in order to reproducibly generate high quality MS and MS/MS spectra for further database searching.

The recoveries and selectivity of $\mathrm{NiZnFe}_{2} \mathrm{O}_{4}$ towards multiphosphopeptides were quantitatively assessed by using a LC approach based on peak areas at $214 \mathrm{~nm}$. As the detection limit of LC is in the level of nmol that is much higher than that of mass spectrometry, it provides a useful means for testing the capacities of $\mathrm{NiZnFe}_{2} \mathrm{O}_{4}$ nanoparticles to selectively isolate multi- phosphopeptides in the presence of huge amounts of monophosphopeptides. A mixture containing $3 \mathrm{nmol}$ of $\mathrm{P} 2$ and $3 \mathrm{nmol}$ of P1 was loaded with $\mathrm{NiZnFe}_{2} \mathrm{O}_{4}$ nanoparticles. For three repeated experiments, recoveries of $\mathrm{P} 2$ were $87 \%, 88 \%$ and $85 \%$ but recoveries of P1 were only $1.4 \%, 1.2 \%$ and $1.5 \%$, respectively (Supplementary Fig. S7).

The performance of $\mathrm{NiZnFe}_{2} \mathrm{O}_{4}$ has also been compared with other approaches including $\mathrm{TiO}_{2}^{27-30}, \mathrm{Fe}^{3+}-\mathrm{IMAC}^{31}$ and HAP (hydroxyapatite) $^{32,33}$ (Supplementary Note 2; Supplementary Table S2). These materials can bind with both mono- and multi- phosphorylated peptides without selectivity (Supplementary Fig. S8). Partial separations of peptides with different degrees of phosphorylation can only be achieved through sequential elutions by using different solvents (Supplementary Figs S9-S11).

Phosphoproteome profiling of zebrafish eggs. As zebrafish share significant similarities in developmental processes with human and other vertebrates, it has emerged as an ideal model to study environmental exposures and risks for developing diseases $^{34}$. In particular, the external fertilization of zebrafish eggs offers additional benefits for such studies. Analysis of changes in protein phosphorylation should be able to reveal the cues for toxic effects of environmental pollutants on fertilization and embryo development ${ }^{35,36}$.

Tryptic peptides of zebrafish egg proteins were first loaded with $\mathrm{NiZnFe}_{2} \mathrm{O}_{4}$ and then the flowthrough fraction was loaded with $\mathrm{Fe}_{3} \mathrm{O}_{4}$. All enriched phosphopeptides were one-step eluted out with $1 \mathrm{M}\left(\mathrm{NH}_{4}\right)_{3} \mathrm{PO}_{4}$ and two distinct peptide pools (Fig. 3a,b; Supplementary Table S3) were obtained. For better separation, multi-phosphopeptides bound with $\mathrm{NiZnFe}_{2} \mathrm{O}_{4}$ were also sequentially eluted out by using gradient $20 \mathrm{mM}, 50 \mathrm{mM}$ and $100 \mathrm{mM}\left(\mathrm{NH}_{4}\right)_{3} \mathrm{PO}_{4}$ (Supplementary Fig. S12). It is not surprising that dominant peaks eluted from $\mathrm{NiZnFe}_{2} \mathrm{O}_{4}$ are multiphosphorylated peptides (Fig. 3a). Several peptides from vitellogenin are found to be highly multi-phosphorylated. Vitellogenin is not only a major precursor of egg-yolk proteins crucial for successful embryonic and larval growth but also has been considered as a useful biomarker for detecting the oestrogenic activity of chemicals in acquatic environment ${ }^{37}$. The biological roles of different levels of phosphorylation events on this protein remain largely unknown ${ }^{38}$. The peak at $m / z=1,964$ was unambiguously identified as DTSSGSA AASFEQMQK with four phosphate groups (Phosphorylated amino acids were indicated by bold characters). A series of peaks with losses of $80 \mathrm{Da}$ masses including $\mathrm{m} / \mathrm{z}=1,884, \mathrm{~m} / \mathrm{z}=1,804$ and $m / z=1,724$ support the presence of multiple phosphate groups. These peaks may result from in source fragmentation that is usually observed in mass spectrometric analysis. An interesting example is the peak at $m / z=2,749$ that was identified as THHGDSKSSRSTGSSLEQIQK with five phosphate groups on all serines except the last one ${ }^{39}$. Although the peak at $m / z=2,829$ was not successfully identified, the $80 \mathrm{Da}$ mass difference indicates that the last $\mathbf{S}$ in this peptide was also phosphorylated. Some other peaks were also not successfully identified due to low abundance or inefficient fragmentation. However, the presence of peaks with losses of $80 \mathrm{Da}$ masses suggests that these peptides have undergone extensive multiphosphorylation. Two obvious series of such peptides include the peaks at $m / z=3,928,3,848,3,768,3,688,3,608,3,528$ and the peaks at $m / z=3,905,3,825,3,745$ and 3,665. Although losses of $80 \mathrm{Da}$ masses are helpful to locate multi-phosphopeptides, the identification of monophosphopeptides becomes challenging. There are no experimental evidences to confirm if monophosphopeptides are produced in source or in vivo. In Fig. 3a, the peak at $m / z=1,724$ is identified as a monophospho- 


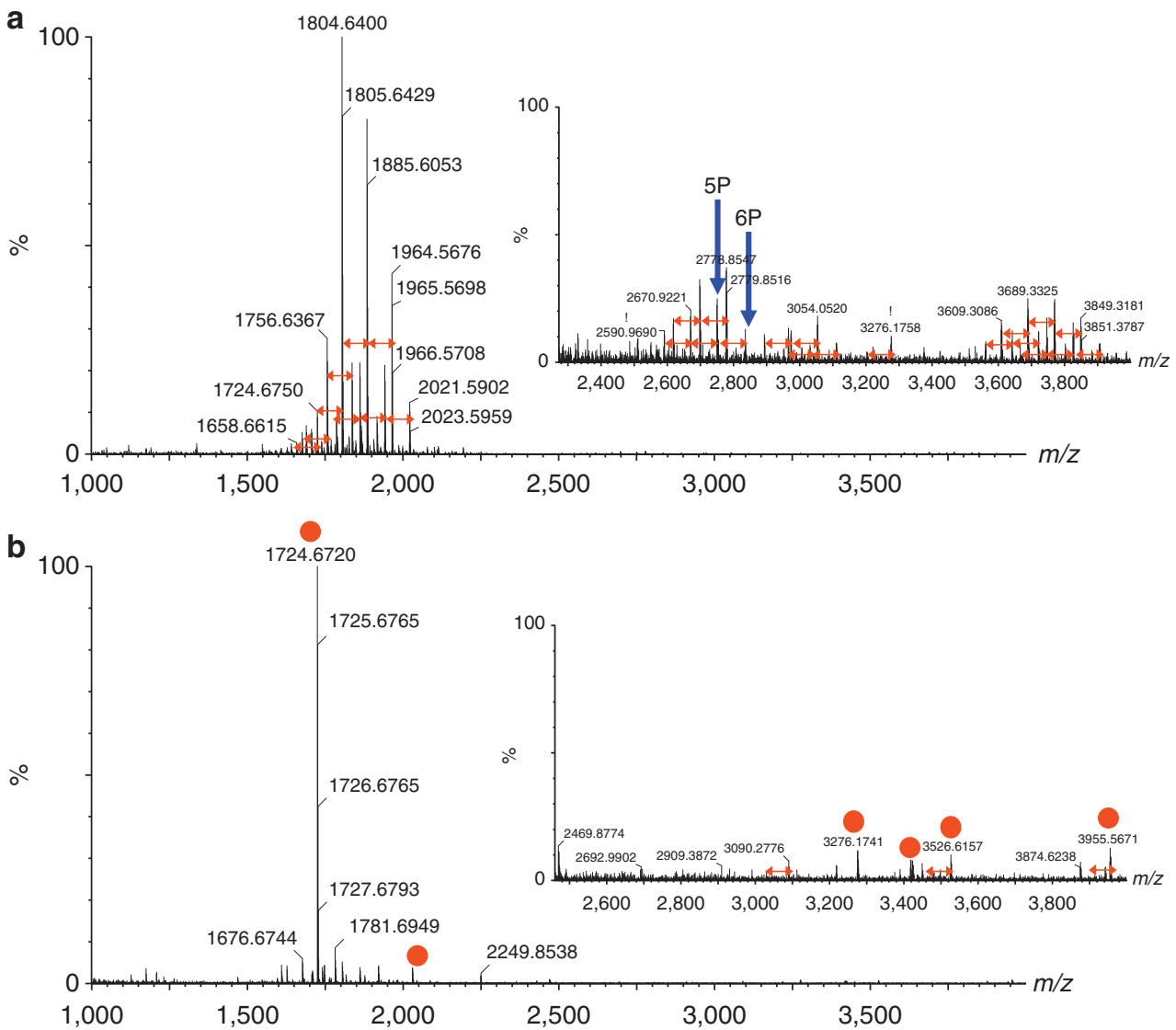

Figure 3 | Phosphoproteome profiling of zebrafish eggs. (a) Mass spectrum of multi-phosphorylated peptides enriched with $\mathrm{NiZnFe}_{2} \mathrm{O}_{4}$ nanoparticles directly from the tryptic digests of zebrafish egg proteins. The blue arrows indicates the peptides containing five and six phosphate groups. (b) Mass spectrum of mono-phosphorylated peptides (labelled as red balls) enriched with $\mathrm{Fe}_{3} \mathrm{O}_{4}$ from the flowthrough fraction of $\mathrm{NiZnFe}_{2} \mathrm{O}_{4}$ nanoparticles. Losses of $80 \mathrm{Da}$ masses were observed probably owing to in source fragmentation, especially for multi-phosphorylated peptides (labelled as red arrows).

peptide DTSSGSAAASFEQMQK. However, the formation of this monophosphopeptide is unknown ${ }^{39}$. Fortunately, the flowthrough fraction of $\mathrm{NiZnFe}_{2} \mathrm{O}_{4}$ has been subsequently enriched with $\mathrm{Fe}_{3} \mathrm{O}_{4}$ (Fig. 3b). The peak at $\mathrm{m} / z=1,724$ becomes the dominant peak which confirms the in vivo production. Other peptides eluted from $\mathrm{Fe}_{3} \mathrm{O}_{4}$ such as peaks at $m / z=3,276, \quad 3,526, \quad 3,955$ and 3,417 have also been unambiguously identified as monophosphopeptides. Without enrichment by $\mathrm{NiZnFe}_{2} \mathrm{O}_{4}$ or $\mathrm{Fe}_{3} \mathrm{O}_{4}$, none of these phosphorylated peptides can be observed (Supplementary Fig. S13).

The same samples have been analysed by $\mathrm{Fe}^{3+}$-IMAC (Supplementary Fig. S14), HAP (Supplementary Fig. S15) and $\mathrm{TiO}_{2}$ approaches ${ }^{39}$. Different degrees of co-elution of mono- and multi- phosphopeptides were observed. Mechanisms of these methods are different and they are all useful tools for exploration of complex biological samples with different research goals. MASCOT searching results were listed in Supplementary Figs S16-S29. Some peptides that have been previously identified by MS/MS database searching ${ }^{39}$ were only identified by MS experiments in the work.

\section{Discussion}

All experimental results show that nanostructured magnetic ferrites, including $\mathrm{Fe}_{3} \mathrm{O}_{4}, \mathrm{NiFe}_{2} \mathrm{O}_{4}, \mathrm{ZnFe}_{2} \mathrm{O}_{4}$ and $\mathrm{NiZnFe}_{2} \mathrm{O}_{4}$, have distinct selectivities towards mono- and multi- phosphorylated peptides. Cubic ferrites have well established spinel structure that is based on a face centred cubic lattice of oxygen ions, forming tetrahedral and octahedral coordination sites ${ }^{40,41}$.
Binding of phosphate groups is dependent on the distribution of metal ions at the surface octahedral sites ${ }^{40} . \mathrm{Fe}_{3} \mathrm{O}_{4}$ has an inverse spinel structure in which $\mathrm{Fe}^{2+}$ and half $\mathrm{Fe}^{3+}$ ions are arranged in octahedral sites and another half $\mathrm{Fe}^{3+}$ ions are arranged in tetrahedral sites $^{42}$. Selective binding of monophosphopeptides with $\mathrm{Fe}_{3} \mathrm{O}_{4}$ indicates that either $\mathrm{Fe}^{2+}$ or $\mathrm{Fe}^{3+}$ at the surface can not efficiently bind with multi-phosphopeptides. Substitution of $\mathrm{Fe}^{2+}$ by magnetic divalent cation $\mathrm{Ni}^{2+}$ maintains the inverse spinel structure ${ }^{43}$. In resultant $\mathrm{NiFe}_{2} \mathrm{O}_{4}, \mathrm{Ni}^{2+}$ and half $\mathrm{Fe}^{3+}$ ions occupy the octahedral sites and another half $\mathrm{Fe}^{3+}$ ions occupy the tetrahedral sites similar as that in $\mathrm{Fe}_{3} \mathrm{O}_{4}$. But the replacement of surface $\mathrm{Fe}^{2+}$ ions by $\mathrm{Ni}^{2+}$ ions alone does not cause significant changes in the binding affinities towards phosphopeptides. Further substitution of $\mathrm{Fe}^{2+}$ by diamagnetic divalent cation $\mathrm{Zn}^{2+}$ results in the formation of a normal spinel structure in which $\mathrm{Zn}^{2+}$ ions occupy the tetrahedral sites and all $\mathrm{Fe}^{3+}$ occupy the octahedral sites ${ }^{44}$. However, the incorporation of $\mathrm{Zn}^{2+}$ also can not make detectable changes. Resultant $\mathrm{ZnFe}_{2} \mathrm{O}_{4}$ still remains similar binding affinities as that of $\mathrm{Fe}_{3} \mathrm{O}_{4}$ and $\mathrm{NiFe}_{2} \mathrm{O}_{4}$. In contrast, $\mathrm{NiZnFe}_{2} \mathrm{O}_{4}$ shows distinct binding selectivity towards multi-phosphorylated peptides. It has mixed $\mathrm{Fe}^{3+} / \mathrm{Ni}^{2}+$ ions at the octahedral sites and mixed $\mathrm{Fe}^{3+} / \mathrm{Zn}^{2+}$ ions at the tetrahedral sites ${ }^{45}$. The experimental results suggest that interactions of cations on octahedral and tetrahedral sites in spinels may contribute to the selective binding affinities towards multiphosphopeptides ${ }^{46}$. It has been reported that the substitution of iron by zinc decreases the area of tetrahedral sublattice as well as the magnetic field of octahedral sublattice but increases the area of octahedral sublattice ${ }^{47}$. As a result, there maybe less steric effects 
and less instable motions caused by the magnetic field when negatively charged multi-phosphopeptides bind with cations at the surface octahedral sites.

In summary, there are mainly two factors that determine the overall coverage of phosphorylation sites by using mNOF. First, the binding affinity of metal ions at surface octahedral sites with phosphopeptides depends on the interactions between negatively charged phosphate groups and positively charged metal ions. Metal ions at the surface octahedral sites offer free coordination sites to accept electron pairs provided by phosphate groups. According to the principle of hard and soft acids and bases described by Pearson ${ }^{48}, \mathrm{Fe}^{3+}$ is classified as a hard Lewis acid. Therefore, $\mathrm{Fe}^{3+}$ theoretically has a strong binding with phosphorylated amino acids that are classified as hard Lewis bases. In this study, all ferrites have $\mathrm{Fe}^{3+}$ or together with $\mathrm{Ni}^{2+}$ at the surface octahedral sites, providing the fundamental structure to coordinate with negatively charged phosphate groups. Second, the selectivity of ferrites towards mono- and multi-phosphorylated peptides is dependent on the interactions of cations at the octahedral and tetrahedral sites. $\mathrm{NiZnFe}_{2} \mathrm{O}_{4}$ is highly selective towards multi-phosphopeptides probably because of the increased area and decreased magnetic field of exposed surface octahedral sublattices.

\begin{abstract}
Methods
Preparation of magnetic nanoparticles of ferrites. $\mathrm{NiZnFe}_{2} \mathrm{O}_{4}$ nanoparticles were purchased from Sigma-Aldrich. $\mathrm{Fe}_{3} \mathrm{O}_{4}, \mathrm{NiFe}_{2} \mathrm{O}_{4}$ and $\mathrm{ZnFe}_{2} \mathrm{O}_{4}$ nanoparticles were prepared by a chemical co-precipitation method described as follows. Otherwise all these nanoparticles can be purchased from Sigma-Aldrich. Stock solutions of $1 \mathrm{M} \mathrm{FeCl}_{3}, \mathrm{FeCl}_{2}, \mathrm{ZnSO}_{4}$ and $\mathrm{Ni}\left(\mathrm{NO}_{3}\right)_{2}$ were prepared in $2 \mathrm{M} \mathrm{HCl}$, respectively. Mix $10 \mathrm{ml}$ of $1 \mathrm{M} \mathrm{FeCl}_{3}$ solution with $5 \mathrm{ml}$ of $1 \mathrm{M} \mathrm{FeCl}_{2}$ solution solely, or together with either $5 \mathrm{ml}$ of $1 \mathrm{M} \mathrm{ZnSO}_{4}$ or $\mathrm{Ni}\left(\mathrm{NO}_{3}\right)_{2}$ solutions at room temperature in order to make ferrites doped with different metal ions. Add ammonium hydroxide to the mixtures drop by drop with stirring until the $\mathrm{pH}$ value of the solutions reached 11-12. Keep stirring at room temperature for $30 \mathrm{~min}$. And then the magnetic nanoparticles were washed three times with water and subsequent three times with ethanol. The morphology of resultant nanoparticles of ferrites has been characterized by Scan Electron Microscope (JEOL, Japan). It was observable that these nanoparticles are essentially uniform. All resultant nanoparticles can be stably dispersed into the sample loading buffer and washing buffer containing 50\% ACN and $0.1 \%$ TFA. Therefore, these nanoparticles are readily accessible to biological samples and can efficiently interact with electron donor groups present in samples. In particular, these nanoparticles not only provide immobilized metal ions such as, $\mathrm{Fe}^{3+}$ and $\mathrm{Ni}^{2+}$ as well as high ratio of surface area to volume for efficient entrapment of phosphopeptides, but they also offer intrinsic magnetic properties to enable rapid isolation of target molecules from a complex mixture within few seconds by a magnetic field. The magnetic nanoparticles were kept with ethanol in a $4{ }^{\circ} \mathrm{C}$ fridge for the following experiments. Before use, these nanoparticles should be washed with pure water.
\end{abstract}

\section{Enrichment of model phosphopeptides with ferrites. Model phosphoprotein} $\alpha$-casein $\left(5 \mu{\left.\mathrm{g} \mathrm{l}^{-1}\right)}^{-1}\right.$ or non-phosphoprotein cytochrome $c\left(5 \mu \mathrm{g} \mu \mathrm{l}^{-1}\right)$ was tryptically digested in $100 \mathrm{mM} \mathrm{NH}_{4} \mathrm{HCO}_{3}$ at a concentration of 50:1 (protein versus trypsin) for $12 \mathrm{~h}$ in a $37^{\circ} \mathrm{C}$ water bath. The final concentration of tryptic peptides was $0.5 \mu \mathrm{gl}^{-1}$. Taken $30 \mu \mathrm{l}$ of tryptic peptides to mix with $100 \mu \mathrm{l}$ of ACN, $69 \mu \mathrm{l}$ of pure water and $1 \mu \mathrm{l}$ of $20 \%$ TFA, so the final loading buffer contained $50 \% \mathrm{ACN}$ and the $\mathrm{pH}$ value was about $1-2$. Then $5 \mathrm{mg}$ of magnetic nanoparticles of different ferrites were added to the mixture. After vortex the mixture for $60 \mathrm{~min}$, the nanoparticles were collected by an external magnetic field. And then the supernatant was discarded. The nanoparticles were first washed three times with the loading buffer containg $50 \% \mathrm{ACN}$ and $0.1 \%$ TFA. In order to elute enriched phosphopeptides, washed nanoparticles were first re-suspended in $100 \mu \mathrm{l}$ of $1 \mathrm{M}$ ammonium phosphate solution and vortexed for $3 \mathrm{~min}$. After collected the supernatant, nanoparticles were then re-suspended in $50 \mu \mathrm{l}$ of $1 \mathrm{M}$ ammonium phosphate solution again and vortexed for another $3 \mathrm{~min}$. Combine all the supernatants into an Eppendorf vial for following MALDI-MS/MS experiments. To obtain a better separation, phosphopeptides have also been gradiently eluted out by using sequential $20 \mathrm{mM}, 50 \mathrm{mM}, 100 \mathrm{mM}$ and $1 \mathrm{M}$ ammonium phosphate solutions, respectively.

In order to evaluate the binding specificities of different ferrites with mono- and multi-phosphopeptides, the flowthrough fractions of $\mathrm{Fe}_{3} \mathrm{O}_{4}$ and $\mathrm{NiZnFe}_{2} \mathrm{O}_{4}$ have been inversely enriched by $\mathrm{NiZnFe}_{2} \mathrm{O}_{4}$ and $\mathrm{Fe}_{3} \mathrm{O}_{4}$, respectively. All downstream procedures such as loading, washing and elution were the same as that described above.
Enrichment of zebrafish egg phosphopeptides with ferrites. Zebrafish eggs were washed three times with $0.675 \%$ saline solution over ice. Then 200 zebrafish eggs were lysed with $200 \mu \mathrm{l}$ lysis buffer that was purchased from Shenergy Biocolor BioScience and Technology (Shanghai, China) in a glass tissue homogenator. The lysis buffer was used together with protease inhibitor containing PMSF $(100 \mathrm{mM})$, Aprotinin $(15 \mu \mathrm{M})$, Leupeptin $(100 \mu \mathrm{M})$, Bestatin $(100 \mu \mathrm{M})$, Pepstatin A $(100 \mu \mathrm{M})$, E-64 $(80 \mu \mathrm{M})$. The non-soluble tissue debris was removed by centrifugation at $16,000 \mathrm{~g}$ for half hour at $4{ }^{\circ} \mathrm{C}$ and the supernatant was pipetted into an Eppendorf vial. Protein concentration was determined by Bradford protein assay reagent according to the manufacturer's instruction. About $1 \mathrm{mg}$ proteins of zebrafish eggs were reduced by dithiothreitol, derived by iodoacetamide and tryptically digested in $0.1 \mathrm{M} \mathrm{NH}_{4} \mathrm{HCO}_{3}$ solution at a concentration of 50:1 (protein versus enzyme) for $12 \mathrm{~h}$ in a $37^{\circ} \mathrm{C}$ water bath. The final concentration of tryptic peptides is $2 \mu \mathrm{g} \mu \mathrm{l}^{-1}$. Pipette $300 \mu \mathrm{g}$ tryptic peptides into two vials containing $10 \mathrm{mg}$ nanoparticles of $\mathrm{Fe}_{3} \mathrm{O}_{4}$ and $\mathrm{NiZnFe}_{2} \mathrm{O}_{4}$, respectively. Add acetonitrile and TFA into the vials so that the final loading buffer contained 50\% acetonitrile and $0.1 \%$ TFA. Similarly, the flowthrough fractions have also been inversely enriched by $\mathrm{NiZnFe}_{2} \mathrm{O}_{4}$ and $\mathrm{Fe}_{3} \mathrm{O}_{4}$. The other procedures for sample loading, washing and elution were the same as that used for the model protein casein. Phosphopeptides have also been eluted out gradiently by using sequential $20 \mathrm{mM}, 50 \mathrm{mM}, 100 \mathrm{mM}$ and $1 \mathrm{M}$ ammonium phosphate solutions, respectively.

Enrichment of phosphopeptides with $\mathrm{TiO}_{2}, \mathrm{HAP}$ and $\mathrm{Fe}^{3+}$-IMAC. The same amount of tryptic peptides of casein or zebrafish egg proteins was also analysed with $5 \mathrm{mg} \mathrm{TiO} 2$, $\mathrm{HAP}$ and $\mathrm{Fe}^{3+}-\mathrm{IMAC} \mathrm{TiO}_{2}$ particles were synthesized by using a sol-gel method ${ }^{39}$. For $\mathrm{TiO}_{2}$ and $\mathrm{Fe}^{3+}-\mathrm{IMAC}$ approach, the loading buffer contains $50 \%$ acetonitrile and $0.1 \%$ TFA. For HAP approach, the loading buffer contains $20 \mathrm{mM}$ Tris- $\mathrm{HCl}(\mathrm{pH} \sim 7.2)$ and $20 \%$ acetonitrile. The loading time for all samples was $60 \mathrm{~min}$. All beads were separated by centrifugation at $16,000 \mathrm{~g}$ for $5 \mathrm{~min}$. For $\mathrm{TiO}_{2}$ approach, the supernatant was discarded and $\mathrm{TiO}_{2}$ particles were sequentially re-suspended in $20 \mathrm{mM}, 50 \mathrm{mM}, 100 \mathrm{mM}$ and $1 \mathrm{M}\left(\mathrm{NH}_{4}\right)_{3} \mathrm{PO}_{4}$ solutions, respectively, in order to gradiently elute out different phosphopeptides. Alternatively, phosphopeptides were one-step eluted out with $1 \mathrm{M}\left(\mathrm{NH}_{4}\right)_{3} \mathrm{PO}_{4}$ solution. Then phosphopeptides were desalted with Millipore C18 ZipTip (MA, USA) and sequentially eluted out by using 5, 10, 20, 30, 50 and $80 \%$ acetonitrile solution containing $0.1 \%$ TFA. For HAP approach, the supernatant was discarded and phosphopeptides were sequentially eluted out from HAP particles with $20 \mathrm{mM}$, $50 \mathrm{mM}, 100 \mathrm{mM}$ and $1 \mathrm{M} \mathrm{Na}_{2} \mathrm{HPO}_{4}(\mathrm{pH} \sim 7.2)$. For $\mathrm{Fe}^{3+}$-IMAC approach, phosphopeptides present in the supernatant was enriched with $\mathrm{TiO}_{2}$ and eluted out with $1 \mathrm{M}\left(\mathrm{NH}_{4}\right)_{3} \mathrm{PO}_{4}$. Phosphopeptides bound with IMAC gels were washed with $20 \%$ acetonitrile containing $1 \%$ TFA and eluted out with $0.5 \%$ ammonia water.

Mass spectrometric analysis. Before mass spectrometric analysis of phosphopeptides, Millipore C18 ZipTip (MA, USA) was used to desalt the elutants containing concentrated salts such as $\left(\mathrm{NH}_{4}\right)_{3} \mathrm{PO}_{4}$ or $\mathrm{Na}_{2} \mathrm{HPO}_{4}$. The ZipTip was first wetted with $50 \%$ acetonitrile and equilibrated with $0.1 \%$ TFA in $\mathrm{H}_{2} \mathrm{O}$. Add $20 \%$ TFA to the elutant in order to reach a $\mathrm{pH} \sim 2$. And then acidified elutant was loaded into the ZipTip. After three cycles of wash with $0.1 \%$ TFA in $\mathrm{H}_{2} \mathrm{O}$, phosphopeptides were directly eluted out with $4 \mu \mathrm{l}$ of $1 \mathrm{M}$ DHB solution containing $50 \%$ acetonitrile and $0.1 \%$ TFA. And each of $0.8 \mu$ l elutant was deposited onto the MALDI plate for full scan MS experiments and MS/MS experiments. In order to identify as many unknown proteins in zebrafish eggs as possible, each sample has been deposited into several spots so as to acquire as many MS/MS spectra as possible. The MALDI experiments were performed on a MALDI Synapt G2 HDMS system (Waters, USA) in the sensitivity mode (V mode). (Glu1)-Fibrinopeptide B was used as the lock-mass for instrumental calibration. All MS spectra and MS/MS spectra were interpreted manually according to the known sequence of the model proteins or by MASCOT searching for unknown proteins in zebrafish eggs.

Quantification of the binding performance of $\mathrm{NiZnFe}_{2} \mathbf{O}_{4}$. Two synthesized peptides were purchased from APeptide Co. Ltd (Shanghai, China) including CysSer-Lys-Asn-Gln-Ile-Ser(p)-Thr-Leu-Asp-Phe-Ser (P1) and Cys-Arg-Gly-Val-HisHis-Ile-Asp-Tyr(p)-Tyr(p)-Lys-Lys-Thr-Ser-Asn (P2). They were mixed together in 1:1 molar ratio. In order to prevent the formation of disulphide bonds, free thiol groups of these synthesized peptides were blocked with NEM ( $N$-ethylmaleimide). Then $10 \mathrm{mg}$ of $\mathrm{NiZnFe}_{2} \mathrm{O}_{4}$ nanoparticles were loaded with the mixture containing $3 \mathrm{nmol}$ of P1 and $3 \mathrm{nmol}$ of P2 (equivalent to $4 \mu \mathrm{g}$ of P1 and $6 \mu \mathrm{g}$ of P2) in a loading buffer $(50 \% \mathrm{ACN}$ and $0.1 \% \mathrm{TFA})$ for $1 \mathrm{~h}$. And then these nanoparticles were extensively washed with the loading buffer and finally eluted out with $1 \mathrm{M}$ $\left(\mathrm{NH}_{4}\right)_{3} \mathrm{PO}_{4}$ solution. The eluted peptides or standard peptides were first acidified with $20 \%$ TFA until pH $2 \sim 3$ before they were injected into an Agilent 1100 HPLC system equipped with a Kromasil C8 chromatographic column $(4.6 \times 150 \mathrm{~mm}$, $5 \mu \mathrm{m}, 300 \mathrm{~A}^{\circ}$ ) for separation. Peaks were detected at $214 \mathrm{~nm}$ and peak areas were obtained through an automatic integration. To determine the detection limit of $\mathrm{NiZnFe}_{2} \mathrm{O}_{4}$ nanoparticles, the same process of sample loading, washing, elution and acidification as described above was performed. The phosphopeptides were then desalted by using a Millipore C18 ZipTip before mixed with CHCA matrix for MALDI analysis. Each sample spot contains 30, 3 and $0.3 \mathrm{pmol}$ of synthesized phosphopeptides P1 and P2, respectively. 


\section{References}

1. Olsen, J. V. et al. Global, in vivo, and site-specific phosphorylation dynamics in signaling networks. Cell 127, 635-648 (2006).

2. Tarrant, M. K. \& Cole, P. A. The chemical biology of phosphorylation. Ann. Rev. Biochem. 78, 797-825 (2009).

3. Cohen, P. The role of protein phosphorylation in human health and disease Eur. J. Biochem. 268, 5001-5010 (2001).

4. Yates, D. Development: directing development through phosphorylation. Nat. Rev. Neurosci. 12, 248-249 (2011).

5. Huang, O. W. et al. Phosphorylation-dependent activity of deubiquitinase DUBA. Nat. Struct. Mol. Biol. 19, 171-175 (2012).

6. Park, K. S., Mohapatra, D. P., Misonou, H. \& Trimmer, J. S. Graded regulation of the Kv3.1 potassium channel by variable phosphorylation. Science 313, 976-979 (2006)

7. Koivomagi, M. et al. Cascades of multisite phosphorylation control Sic1 destruction at the onset of S phase. Nature 480, 128-132 (2011).

8. Bivona, T. G. et al. PKC regulates a farnesyl-electrostatic switch on K-Ras that promotes its association with Bcl-XL on mitochondria and induces apoptosis. Mol. Cell 21, 481-493 (2006).

9. Lee, C. W., Ferreon, J. C., Ferreon, A. C. M., Arai, M. \& Wright, P. E. Graded enhancement of $\mathrm{p} 53$ binding to CREB-binding protein (CBP) by multisite phosphorylation. Proc. Natl Acad. Sci. USA 107, 19290-19295 (2010).

10. Vicente-Manzanares, M. \& Horwitz, A. R. Myosin light chain mono- and di-phosphorylation differentially regulate adhension and polarity in migrating cells. Biochem. Biophy. Res. Comm 402, 537-542 (2010).

11. Deng, X., Gao, F., Flagg, T. \& May, Jr W. S. Proc. Natl Acad. Sci. USA 101, 153-158 (2004)

12. Sim, R. J. \& Reinberg, D. Is there a code embedded in proteins that is based on posttranslational modification? Nat. Rev. Mol. Cell Biol 9, 815-820 (2008).

13. Cohen, P. The regulation of protein function by multisite phosphorylation: a 25 year update. Trends Biochem. Sci 25, 596-601 (2000).

14. Chan, C. et al. Protein scaffolds can enhance the bistability of multisite phosphorylation systems. PLoS Comput. Biol. 8, e1002551 (2012).

15. Son, S., Taheri, M., Carpenter, E., Harris, V. G. \& McHenry, M. E. Synthesis of ferrite and nickel ferrite nanoparticles using radio-frequency thermal plasma torch. J. Appl. Phys. 91, 7589-7591 (2002).

16. Muralidharan, S., Saraswathy, V., Berchmans, L. J., Thangavel, K. \& Ann, K. Y. Nickel ferrite $\left(\mathrm{NiFe}_{2} \mathrm{O}_{4}\right)$ : a possible candidate material as reference electrode for corrosion monitoring of steel in concrete. Sens. Actuators B 145, 225-231 (2010).

17. Albuquerque, A. S. et al. Nanostructured ferrites: structural analysis and catalytic activity. Ceramics Inter. 38, 2225-2231 (2012).

18. Chen, C. J., Bridger, K., Winzer, S. R. \& PaiVerneker, V. A novel lowtemperature preparation of $\mathrm{Ni}-\mathrm{Zn}$ ferrite and the properties of the ultrafine particles formed. J. Appl. Phys. 63, 3786-3788 (1988).

19. Maaz, K. et al. Synthesis and magnetic characterization of nickel ferrite nanoparticles prepared by co-precipitation route. J. Magn. Magn. Mater. 321, 1838-1842 (2009).

20. Lelis, M. M. M., Fabris, J. D., Mussel, W. N. \& Takenchi, A. Y. Preparation and characterization of nickel-and cobalt-doped magnetites. Mat. Res 6, 145-150 (2003).

21. Kinemuchi, Y., Ishizaka, K., Suematsu, H., Jiang, W. \& Yatsui, K. Magnetic properties of nanosize $\mathrm{NiFe}_{2} \mathrm{O}_{4}$ particles synthesized by pulse wire discharge. Thin. Solid Films 407, 109-113 (2002).

22. Wenzel, M. J. \& Steinle-Neumann, G. Nonequivalence of the octahedral sites of cubic $\mathrm{Fe}_{3} \mathrm{O}_{4}$ magnetite. Phys. Rev. B 75, $214430-214436$ (2007).

23. Porath, J. IMAC-Immobilized metal ion affinity based chromatography. Trends in Anal. Chem. 7, 254-259 (1988)

24. Villen, J. \& Gygi, S. P. The SCX/IMAC enrichment approach for global phosphorylation analysis by mass spectrometry. Nat. Methods 3, 1630-1638 (2008).

25. Zhang, X., Ye, J., Jensen, O. N. \& Roepstorff, P. Highly efficient phosphopeptide enrichment by calcium phosphate precipitation combined with subsequent IMAC enrichment. Mol. Cell. Proteomics 6, 2032-2042 (2007).

26. Thingholm, T. E., Jorgensen, T. J. D., Jensen, O. N. \& Larsen, M. R. Highly selective enrichment of phosphorylated peptides using titanium dioxide. Nat. Protoc. 1, 1929-1935 (2006).

27. Choi, S. et al. Sequential $\mathrm{Fe}_{3} \mathrm{O}_{4} / \mathrm{TiO}_{2}$ enrichment for phosphopeptide analysis by liquid chromatography/tandem mass spectrometry. Rap. Commun. Mass Spectrom 24, 1467-1474 (2010).

28. Lu, Z., Ye, X., Li, N., Zhong, W. \& Yin, D. Self-assembled $\mathrm{TiO}_{2}$ nanocrystal clusters for selective enrichment of intact phosphorylated proteins. Angew. Chem. Int. Ed. 49, 1862-1866 (2010).

29. Lu, Z., Duan, J., He, L., Hu, Y. \& Yin, D. Mesoporous $\mathrm{TiO}_{2}$ nanocrystal clusters for selective enrichment of phosphopeptides. Anal. Chem. 82, 7249-7258 (2010).

30. Zhou, H. et al. Zirconium phosphonate-modified porous silicon for highly specific capture of phosphopeptides and MALDI-TOF MS analysis. J. Proteome Res. 5, 2431-2437 (2006).
31. Thingholm, T. E., Jensen, O. N., Robinson, P. J. \& Larsen, M. R. SIMC (Sequential Elution from IMAC), a phosphoproteomics strategy for the rapid separation of monophosphorylated from multiply phosphorylated peptides. Mol. Cell. Proteomics 7, 661-671 (2008).

32. Mamone, G., Picariello, G., Ferranti, P. \& Addeo, F. Hydroxyapatite affinity chromatography for the highly selective enrichment of mono- and multiphosphorylated peptides in phosphoproteome analysis. Proteomics 10, 380-393 (2010).

33. Fonslow, B. R. et al. Single-step inline hydroxyapatite enrichment facilitates identification and quantitation of phosphopeptides from mass-limited proteomes with MudPIT. J. Proteome Res. 11, 2697-2709 (2012).

34. Lieschke, G. J. \& Currie, P. D. Animal models of human disease: zebrafish swim into view. Nat. Rev. Genet. 8, 353-367 (2007).

35. Sharma, D. \& Kinsey, W. H. Fertilization triggers localized activation of Src-family protein kinase in the zebrafish egg. Dev. Biol 295, 604-614 (2006)

36. Lemeer, S. et al. Endogenous phosphotyrosine signaling in zebrafish embryos. Mol. Cell. Proteomics 6, 2088-2099 (2007).

37. Sumpter, J. P. \& Jobling, S. Vitellogenesis as a biomarker for estrogenic contamination of the aquatic environment. Environ. Health Perspect 103, 173-178 (1995).

38. Wahli, W., Dawid, I. B., Ryffel, G. U. \& Weber, R. Vitellogenesis and vitellogenin gene family. Science 212, 298-304 (1981).

39. Zheng, S. et al. Desalting of phosphopeptides by tandem polypyrrole-C18 reverse phase micropipette tip (TMTIP ${ }_{\mathrm{PPY}-\mathrm{Cl} 18}$ ) based on hybrid electrostatic, $\Pi-\Pi$ stacking and hydrophobic interactions for mass spectrometric analysis. Anal. Chim. Acta 724, 73-79 (2012).

40. Chen, J., Wang, F., Huang, K., Liu, Y. \& Liu, S. Preparation of $\mathrm{Fe}_{3} \mathrm{O}_{4}$ nanoparticles with adjustable morphology. J. Alloy. Comp. 475, 898-902 (2009).

41. Szotek, Z. et al. Electronic structures of normal and inverse spinel ferrites from first principles. Phys. Rev. B 74, 174431 (2006).

42. Sickafus, K. E. \& Wills, J. M. Structure of spinel. J. Am. Ceram. Soc. 82, 3279-3292 (1999).

43. Ivanov, V. G., Abrashev, M. V., Iliev, M. N., Gospodinov, M. M., Meen, J. \& Aroyo, M. I. Short-range B-site ordering in the reverse spinel ferrite $\mathrm{NiFe}_{2} \mathrm{O}_{4}$. Phys. Rev. B 82, 024104 (2010).

44. Chinnasamy, C. N. et al. Magnetic properties of nanostructured ferrimagnetic zinc ferrite. J. Phys: Condens. Matter. 12, 7795-7805 (2000).

45. Adriana, S. A., Jose, D. A. \& Waldermar, A. A. W. Nanosized powders of NiZn ferrite: synthesis, structure and magnetism. J. Appl. Phy 87, 4352-4357 (2000).

46. Urusov, V. S. Interaction of cations on octahedral and tetrahedral sites in simple spinels. Phys. Chem. Minerals 9, 1-5 (1983).

47. Sorescu, M., Diamandescu, L., Peelamedu, R., Roy, R. \& Yadoji, P. Structural and magnetic properties of NiZn ferrites prepared by microwave sintering. J. Magn. Magn. Mater. 279, 195-201 (2004).

48. Pearson, R. G. Acids and Bases. Science 151, 172-177 (1966).

\section{Acknowledgements}

We greatly appreciate the support from National Natural Science Foundation of China (NSFC 21175054 and 31270876), Program for Changjiang Scholars and Innovative Research Team in University (PCSIRT, no. IRT0953), Hubei Natural Science Foundation Council (HBNSFC, 2009CDA001), Research Funds of Central China Normal University from the Ministry of Education (120002040270, CCNU11G01007, CCNU11C01002) and the Research Platform of Hubei Province for Monitoring of Pesticide Residues and Agricultural Products Safety.

\section{Author contributions}

H.Z. developed the original concept, designed the experiments, analysed the data and wrote the manuscript. X.X. conducted the experiments on enrichment of phosphopeptides with different ferrites and other materials as well as mass spectrometric analysis. S.Z. repeated the experiments for nano-ferrite enrichment and optimization of experimental conditions, performed quantitative assessment of $\mathrm{NiZnFe}_{2} \mathrm{O}_{4}$ and prepared art works. W.Z. have participated in the experiments for $\mathrm{NiZnFe}_{2} \mathrm{O}_{4}$ assessment. M.D. and H.J. conducted the experiments on non-phosphopeptides and reviewed part of the experimental data. L.H. and J.K. have been involved in the experiments.

\section{Additional information}

Supplementary Information accompanies this paper at http://www.nature.com/ naturecommunications

Competing financial interests: The authors declare no competing financial interests

Reprints and permission information is available online at http://npg.nature.com/ reprintsandpermissions/

How to cite this article: Zhong, H. et al. Mass spectrometric analysis of mono- and multi- phosphopeptides by selective binding with $\mathrm{NiZnFe}_{2} \mathrm{O}_{4}$ magnetic nanoparticles. Nat. Commun. 4:1656 doi: 10.1038/ncomms2662 (2013). 